\title{
References
}

Björnsson, H. 1982: Drainage basins on the Vatnajökull mapped by radio echo soundings. Nordic $\mathrm{Hy}$ drol. 13(4), 213-232.

Björnsson, H. 1986: Delineation of glacier drainage basins on western Vatnajökull. Annals Glaciol. 9, 19-21.

Briggs, I. C. 1974: Machine contouring using minimum curvature. Geophysics 39, 39-49.

Hodge, S. M. 1978: USGS Mono-pulse Ice Radar. Unpubl. intern. USGS rep., 10 pp.

Olesen, O. B. 1986: Fourth year of glaciological field work at Tasersiaq and Qapiarjiup sermia, West Greenland. Rapp. Grønlands geol. Unders. 130, 121-126.

Thomsen, H. H. 1983: A glaciological field and mapping programme in connection with hydropower, West Greenland. Rapp. Grønlands geol. Unders. 115, 102-107.

Thomsen, H. H., Thorning, L. \& Braithwaite, R. 1986: Vurdering af de gletscher-hydrologiske forhold på Indlandsisen ved Paakitsup Akuliarusersua, Ilulissat/Jakobshavn. Arbejdsnotat. Geol. Surv. Greenland, $82 \mathrm{pp}$.

Thorning, L. 1982: Processing and interpretation of aeromagnetic data in The Geological Survey of Greenland. Rapp. Grønlands geol. Unders. 114, 41 pp.

Thorning, L., Thomsen, H. H. \& Hansen, E. 1986: Geophysical investigations at the Inland Ice margin of the Pâkitsoq basin, central West Greenland. Rapp. Grønlands geol. Unders. 130, 114-121.

\section{The last full summer of glacier-climate investigations at Qamanârssûp sermia, West Greenland}

\author{
Roger J. Braithwaite
}

As part of the GGU programme of hydropower investigations in West Greenland, glaciological and climatological measurements were continued at Qamanârssûp sermia in 1986. The station was first established in the late summer of 1979 so that records for seven complete summers 1980-1986 are now available. Brief reports on the work have been given by Olesen (1981), Olesen \& Braithwaite (1982), Braithwaite (1983a, 1984, 1985a, 1986a). More detailed analyses and presentations of data are given in Braithwaite \& Olesen (1982) and Braithwaite (1983b, 1985b).

According to present plans, the Qamanârssûp sermia station will not be manned again for a full summer as it has been for the last seven years. However, a reduced programme of measurements will be continued in future years. A brief discussion of future plans is given at the end of this report.

\section{Field work 1986}

When the first field party arrived in the area in late May, there was obviously more snow accumulation on the glacier than usual. However, from talking to people in Nuuk, and from observations in snow pits, it was obvious that most of the snow was of recent origin, i.e. from 
Table 1. Climatological data summary for base camp, Qamanârssûp sermia 19801986

\begin{tabular}{lcccc}
\hline & June & July & August & Summer \\
\hline Monthly mean temperature $\left({ }^{\circ} \mathrm{C}\right)$ & & & & \\
1980 & 4.7 & 6.6 & 5.5 & 5.6 \\
1981 & 5.2 & 7.5 & 3.9 & 5.5 \\
1982 & 4.9 & 6.0 & 4.3 & 5.1 \\
1983 & 3.3 & 5.2 & 1.8 & 3.4 \\
1984 & 4.4 & 7.5 & 4.7 & 5.5 \\
1985 & 5.6 & 6.4 & 6.2 & 6.1 \\
1986 & 2.6 & 7.0 & 6.0 & 5.2 \\
Mean & 4.4 & 6.6 & 4.6 & 5.2
\end{tabular}

Monthly precipitation ( $\mathrm{mm}$ )

$\begin{array}{lrrrr}1980 & 20 & 61 & 64 & 145 \\ 1981 & 27 & 148 & 81 & 256 \\ 1982 & 8 & 111 & 55 & 174 \\ 1983 & 101 & 102 & 190 & 393 \\ 1984 & 16 & 77 & 139 & 232 \\ 1985 & 120 & 15 & 68 & 203 \\ 1986 & 46 & 94 & 79 & 219 \\ \text { Mean } & 48 & 87 & 97 & 232\end{array}$

\begin{tabular}{lcccc} 
Global radiation $\left(\mathrm{MJ} \mathrm{m}^{-2}\right)$ & & & \\
1980 & $\mathbf{( 6 0 5 )}$ & $(624)$ & $(584)$ & $(1813)$ \\
1981 & 633 & 577 & 391 & 1601 \\
1982 & 711 & 493 & 471 & 1675 \\
1983 & 582 & 487 & 379 & 1448 \\
1984 & 702 & 543 & 291 & 1536 \\
1985 & 535 & 601 & 471 & 1607 \\
1986 & 601 & 567 & 358 & 1526 \\
Mean & 624 & 556 & 421 & 1601 \\
\hline
\end{tabular}

$0=$ calculated from sunshine duration

snow falls in spring rather than in winter. It was unfortunately not possible to get a complete set of measurements of accumulation on the glacier in early June.

The routine climatological and glaciological measurements were started on 31 May at base camp and continued until 31 August. The main observations were daily readings of the three '751' stakes, close to the glacier edge, together with climatological observations at base camp. Readings of transient balances were made several times during the season within a network of stakes extending up to $1410 \mathrm{~m}$ a.s.l. The positions of these stakes were also surveyed three times during the summer by triangulation from fixed points on bedrock.

An energy balance station was operated in $\mathbf{1 9 8 6}$ by Aarhus University as a follow-up of the measurements in 1984 (Knudsen et al., this report). Measurements were also continued by an automatic climate station established by the Greenland Technical Organization (GTO) at base camp. 
Table 2. Ablation at the three '751' stakes, Qamanârssûp sermia 1980-1986

\begin{tabular}{lcccccc}
\hline & June & July & August & Sum & Year & Sum/year \% \\
\hline 1980 & $(0.91)$ & 1.33 & 1.01 & 3.25 & 4.09 & 79 \\
1981 & $(1.11)$ & 1.86 & 0.80 & 3.77 & 4.69 & 80 \\
1982 & 1.07 & 1.58 & 1.16 & 3.81 & 4.66 & 82 \\
1983 & 0.89 & 1.46 & 0.57 & 2.92 & 3.74 & 77 \\
1984 & $(1.00)$ & 1.70 & $(1.11)$ & 3.81 & 4.26 & 89 \\
1985 & $(1.46)$ & 1.53 & $(1.45)$ & 4.44 & 5.88 & 76 \\
1986 & $(0.57)$ & 1.70 & $(1.46)$ & 3.73 & 4.46 & 84 \\
Mean & 1.00 & 1.59 & 1.08 & 3.68 & 4.54 & 81 \\
\hline
\end{tabular}

$0=$ adjusted to full month

Ablation for the three summer months as well as for the year (1 September to 31 August).

Units are metres of water.

\section{Climatological and glaciological situation}

A selected summary is given in Table 1 of climatological data from base camp, Qamanârssûp sermia, for the seven years 1980-1986. June 1986 was exceptionally cold, while July was warmer than average and August was very warm. Precipitation for June and July was close to average while August was relatively dry. Income of global radiation for June and July was close to average while August had very low global radiation. Overall, summer mean temperature and total precipitation were both close to average, while total global radiation was low.

The corresponding statistics for ablation at the '751' stakes are shown in Table 2. Ablation was exceptionally low in June, slightly higher than average in July and exceptionally high in August. These ablation variations follow variations of temperature rather than global radiation in agreement with Braithwaite \& Olesen (1985). The low ablation in June and high ablation in August more or less compensated so that the total summer ablation was close to average for the seven years.

\section{Future plans}

The investigations at Qamanârssûp sermia will be continued but to a reduced extent. For example, the major costs of the programme up to now have been for keeping the station manned throughout the summer which was necessary in its time because some data, especially ablation readings, could only be collected by hand, while there was a reluctance at the start of the investigations to rely upon the automatic climate station as the only means of collecting climatological data. However, the present programme has shown the automatic climate station to be quite reliable and accurate (Braithwaite, 1983c).

In future the station will be visited briefly in spring and in autumn to measure transient balances and redrill stakes.

Table 3 compares the planned data collection of the future programme with the present manned one. The main losses of glaciological data will be daily ablation and ice movement. A reduction in ablation stakes may be necessary if there is not enough time to redrill them 
Table 3. Comparison of planned data collection by a future programme at Qamanârssûp sermia with the present

\begin{tabular}{lccc}
\hline \multicolumn{1}{c}{ Data } & Time-scale & $\begin{array}{c}\text { Present } \\
\text { programme }\end{array}$ & $\begin{array}{c}\text { Future } \\
\text { programme }\end{array}$ \\
\hline $\begin{array}{l}\text { Glaciology } \\
\text { Ablation, '751' stakes }\end{array}$ & Daily & Yes & No \\
& Seasonal & Yes & Yes \\
Ablation, other stakes & Seasonal & Yes & Yes* \\
Ice movement & Seasonal & Yes & No \\
Climatology & & & Yes \\
Air temperature & Daily & Yes & Yes \\
Wind speed & Daily & Yes & Yes? \\
Precipitation & Daily & Yes & Yes? \\
Humidity & Daily & Yes & No \\
Radiation/sunshine & Daily & Yes & No \\
Potential evaporation & Daily & Yes & \\
\hline
\end{tabular}

* Probably with fewer stakes.

all, but crucial stakes can be identified by Lliboutry's linear model (Braithwaite, 1986b). On the climatological side, the main losses will be global radiation and sunshine duration, and potential evaporation data. However, the former are found to be poorly correlated with ablation (Braithwaite \& Olesen, 1985) while the latter measurements were never of high priority. With the automatic climate station there is still doubt about the reliability of precipitation and humidity data (denoted by the question marks in Table 3). More fundamentally, reliance on the automatic weather station raises the spectre of 'single point failure' whereas the risks of failure at a manned station are spread more evenly.

\section{References}

Braithwaite, R. J. 1983a: Glaciological and climatological investigations at Qamanârssûp sermia, West Greenland. Rapp. Grønlands geol. Unders. 115, 111-114.

Braithwaite, R. J. 1983b: Glaciological investigations at Qamanârssûp sermia, interim report 1982 and appendix tables. Grønlands geol. Unders. Gletscher-hydrol. Meddr 83/4, 49 pp.

Braithwaite, R. J. 1983c: Comparisons between automatic and manual climate stations at Qamanârssûp sermia. Grønlands geol. Unders. Gletscher-hydrol. Meddr 83/5, $17 \mathrm{pp}$.

Braithwaite, R. J. 1984: Glaciological and climatological investigations at Qamanârssûp sermia, West Greenland. Rapp. Grønlands geol. Unders. 120, 109-112.

Braithwaite, R. J. 1985a: Glacier-climate investigations in 1984 at Qamanârssûp sermia, West Greenland. Rapp. Grønlands geol. Unders. 125, 108-112.

Braithwaite, R. J. 1985b: Glaciological investigations at Qamanârssûp sermia, West Greenland, 19831984. Grønlands geol. Unders. Gletscher-hydrol. Meddr 85/3, 26 pp.

Braithwaite, R. J. 1986a: Exceptionally high ablation in 1985 at Qamanârssûp sermia, West Greenland. Rapp. Grønlands geol. Unders. 130, 126-129.

Braithwaite, R. J. 1986b: Assessment of mass-balance variations within a sparse stake network, Qamanârssûp sermia, West Greenland. J. Glaciol. 110(32), 50-53. 
Braithwaite, R. J. \& Olesen, O. B. 1982: Glaciological investigations at Qamanârssûp sermia. Field report 1979-1981 and appendix tables. Grønlands geol. Unders. Gletscher-hydrol. Meddr 82/2, 58 pp.

Braithwaite, R. J. \& Olesen, O. B. 1985: Ice ablation in West Greenland in relation to air temperature and global radiation. Z. Gletscherk. Glazialgeol. 20(1984), 155-168.

Olesen, O. B. 1981: Glaciological investigations at Qamanârssûp sermia, West Greenland. Rapp. Grønlands geol. Unders. 105, 60-61.

Olesen, O. B. \& Braithwaite, R. J. 1982: Glaciological investigations at Qamanârssûp sermia, West Greenland. Rapp. Grønlands geol. Unders. 110, 88-90.

\title{
Energy balance on outlet glaciers from the Inland Ice, West Greenland
}

\author{
N. Tvis Knudsen, O. Ottosen and L. M. Svendsen
}

As part of the GGU programme of hydropower investigations in West Greenland, energy balance measurements were made on Qamanârssûp sermia during the 1986 ablation season. The investigations are the continuation of a project in which Aarhus University has measured energy balances on Nordbogletscher, Johan Dahl Land, in 1981 and 1982 and on Qamanârssûp sermia in 1984 in collaboration with P. Clement and R. J. Braithwaite, respectively (fig. 1).

The main point of the programme was direct calculation of the ablation at the glacier surface from observations in the atmospheric boundary layer. Measured ablation was also used to calculate the residual part of the energy balance, as all elements were not determined. Lastly, the ablation was evaluated using variables chosen by correlation between easily measured climatic elements and the energy balance.

The measurements in Johan Dahl Land were made by Jens Peter Jensen and Ole Ottosen as part of a student thesis project. Ole Bendixen undertook field measurements in 1984 on Qamanârssûp sermia while Ole Ottosen and Lars Moeslund Svendsen carried out the field work in 1986.

\section{Johan Dahl Land}

Energy balance measurements were carried out in the middle lower part of Nordbogletscher about $800 \mathrm{~m}$ a.s.l. from mid-July to early September in both years. The energy balance station was situated over an ice surface which developed from a smooth to an undulating topography during the measuring period.

Net radiation was measured directly and the turbulent fluxes were calculated from measured vertical profiles of temperature, wind and humidity. The investigations were described by Jensen (1986) and Ottosen (1986).

Table 1 shows that radiation is generally the main source of ablation energy, although turbulent energy flux provides the main contribution during cyclonic weather. Despite this, Table 2 reveals the absence of a positive correlation between measured ablation and radi- 